\title{
Voltammetric Quantification of Phytoesterone 1-[5-(1, 3- Benzodioxol-5-yl)-1-oxo-2, 4-pentadienyl] Piperidine
}

\author{
Rajeev Jain " and Alka Verma \\ School of Studies in Chemistry, Jiwaji University, Gwalior (M.P.) - 474011, India \\ *E-mail: rajeevjain54@yahoo.co.in
}

doi: $10.20964 / 2017.04 .29$

Received: 25 July 2016 / Accepted: 8 February 2017 / Published: 12 March 2017

\begin{abstract}
A simple one step electroanalytical method has been developed for the first time for the quantification of antioxidant piperine at glassy carbon based sensor. Piperine is primary bioactive component of pepper which has gained a great deal of attention from researchers all over the world due to its wide range of potential biological applications as an antioxidant and anti-carcinogenic agent. In the present study electrochemical behavior of piperine was investigated using square wave voltammetry. The reaction kinetics was studied and experimental conditions were optimized. The voltammetric studies of piperine at glassy carbon electrode exhibited a well defined cathodic peak for its reduction in BrittonRobinson buffer at $\mathrm{pH}$ 7.36. Under optimized experimental condition the square wave reduction peak current was linear over concentration range 8 to $48 \mu \mathrm{g} / \mathrm{mL}\left(\mathrm{R}^{2}=0.995\right)$ with limit of detection (LOD) and limit of quantification of $2.4 \mu \mathrm{g} / \mathrm{mL}$ and $8.1 \mu \mathrm{g} / \mathrm{mL}$ respectively. Developed method was successfully employed for the analysis of piperine in real samples.
\end{abstract}

Keywords: Antioxidant, Piperine, Phytoesterone, Voltammetry

\section{$\underline{\text { FULL TEXT }}$}

(C) 2017 The Authors. Published by ESG (www.electrochemsci.org). This article is an open access article distributed under the terms and conditions of the Creative Commons Attribution license (http://creativecommons.org/licenses/by/4.0/). 